\title{
Resenha
}

\section{Cruzando Histórias - Ciência, Literatura e Civilidade}

Greciene Lopes dos Santos ${ }^{1}$

Pinto Neto, Pedro da Cunha. Ciência, literatura e civilidade. Bragança Paulista: EDUSF, 2006. 226p. ( Estudos CDAPH. Série Historiografia).

A idéia da existência de uma ligação entre a ciência e a cultura, de modo geral, é consensual em nosso meio intelectual. Nesse sentido o livro Ciência, Literatura $e$ civilidade, do químico e pesquisador Pedro da Cunha Pinto Neto, faz uma incursão em romances brasileiros produzidos no final do século XIX e início do século XX. O autor buscou compreender a produção de representações sobre a ciência e o fazer científico, num momento em que as iniciativas de constituição de centros de formação e pesquisa científica, no Brasil, ainda eram incipientes. Dos dez romances selecionados e analisados, a maior parte possui edições recentes e compõe a nossa literatura escolar. São eles: A Carne (1888), O Mulato (1881), Casa de Pensão (1884), O Coruja (1889) e O Cortiço (1890), O Ateneu (1888), Normalista (1893), Recordações do Escrivão Isaías Caminha (1909), Triste fim de Policarpo Quaresma (1911) e Clara dos Anjos (1922).

Organizado em quatro capítulos, no primeiro deles, “Espíritos Superiores”, o leitor encontrará um texto que faz a leitura do romance A Carne de Júlio Ribeiro. O autor a tem como uma obra exemplar, na qual é possível observar os diferentes recursos que são usados na inserção das referências à ciência no romance e das concepções sobre o papel da ciência, entendida tanto como uma prática, quanto componente da formação moral e intelectual dos sujeitos.

No segundo capítulo, "Distintos Cavaleiros”, as obras analisadas foram: O Mulato; Casa de Pensão; O Cortiço e O Coruja. No universo que Aluísio Azevedo constrói e expressa através dessas obras, as relações com o conhecimento e a inserção dos indivíduos no mundo do saber se fazem em função dos interesses e de determinadas peculiaridades do caráter e personalidade de cada um. Estabelece-se que o sentido para a

Mestranda Programa de Pós-Graduação FAE-UFMG

Laboratório de Estudos Museu e Educação (LEME) FAE - UFMG

e-mail:grecienelopes@yahoo.com.br 
ciência e o conhecimento na vida dos sujeitos se manifestam de formas distintas, em função das características individuais que cada um possue.

No capítulo três, “Educação Moderna”, a leitura de O Ateneu de Raul Pompéia e A Normalista de Adolfo Caminha, nos revela um conjunto de referências nas quais a escola e a vida escolar foram representadas pela literatura no final do século XIX. Nestes dois romances, o ambiente e o cotidiano escolar fazem parte da vida dos personagens. Sendo assim, aparecem elementos que são próprios dos programas e das atividades de ensino, havendo referências ao ensino das "ciências naturais", assim como aos aparelhos e outros dispositivos que estão relacionados com esta disciplina. E em "Perigos da Leitura", o quatro capítulo, temos: Recordações do Escrivão Isaías Caminha, Triste fim de Policarpo Quaresma e Clara dos Anjos, de Lima Barreto, nestas obras o autor dá uma nova dimensão às relações entre a ciência e a literatura do período. Escrevendo num país em que a maioria da população era analfabeta, considera a capacidade de leitura um instrumento de distinção social, Lima Barreto mostra a sua indignação com uma elite que cultua os títulos e busca laurear-se de sapiência.

Nos destinos dos personagens, descrito pelos romances, a ciência compõe a vida, define lugares e ações, constitui-se em objeto de desejo. Em cada obra a relação personagem e ciência tem suas particularidades, embora o conjunto apresente elementos comuns, como a relação dos diversos personagens com a ciência, que aqui aparece representada através de uma formação livresca, pois são os livros ou a formação escolar, que colocam os personagens em contato com este conhecimento.

Ao final do texto faz-se o cruzamento de algumas histórias, buscando identificar as homologias e antíteses, procurando assim compor um quadro das diferentes formas pelas quais a ciência foi representada num determinado momento histórico.

“Ciência, Literatura e Civilidade” é portanto, uma obra de interesse a todos aqueles que tem a ciência e a literatura como objeto de estudo e um convite à troca experiêncial, pressupondo que quem o ler fará suas considerações ao texto e às narrativas que o compõem. Este livro é também um convite a leitura ou releitura dos romances analisados, com um novo olhar.

Data de recebimento: 16/06/2008

Data de aprovação: 30/06/2008 